\title{
Characterisation of the paralytic shellfish toxin biosynthesis gene clusters in Anabaena circinalis AWQCI 3 IC and Aphanizomenon sp. NH-5
}

\author{
Troco K Mihali1 ${ }^{1}$ Ralf Kellmann² and Brett A Neilan*1
}

Address: ${ }^{1}$ School of Biotechnology and Biomolecular Sciences, The University of New South Wales, Sydney, NSW 2052, Australia and ${ }^{2}$ Department of Molecular Biology, University of Bergen, P.O. Box 7803, 5020 Bergen, Norway

Email: Troco K Mihali - troco@unsw.edu.au; Ralf Kellmann - ralf.kellmann@mbi.uib.no; Brett A Neilan* - b.neilan@unsw.edu.au

* Corresponding author

Published: 30 March 2009

BMC Biochemistry 2009, 10:8 doi:10.1186/147|-2091-10-8
Received: 14 August 2008

Accepted: 30 March 2009

This article is available from: http://www.biomedcentral.com/I47I-209///0/8

(C) 2009 Mihali et al; licensee BioMed Central Ltd.

This is an Open Access article distributed under the terms of the Creative Commons Attribution License (http://creativecommons.org/licenses/by/2.0), which permits unrestricted use, distribution, and reproduction in any medium, provided the original work is properly cited.

\begin{abstract}
Background: Saxitoxin and its analogues collectively known as the paralytic shellfish toxins (PSTs) are neurotoxic alkaloids and are the cause of the syndrome named paralytic shellfish poisoning. PSTs are produced by a unique biosynthetic pathway, which involves reactions that are rare in microbial metabolic pathways. Nevertheless, distantly related organisms such as dinoflagellates and cyanobacteria appear to produce these toxins using the same pathway. Hypothesised explanations for such an unusual phylogenetic distribution of this shared uncommon metabolic pathway, include a polyphyletic origin, an involvement of symbiotic bacteria, and horizontal gene transfer.

Results: We describe the identification, annotation and bioinformatic characterisation of the putative paralytic shellfish toxin biosynthesis clusters in an Australian isolate of Anabaena circinalis Aphanizomenon sp Nostocales

gene clusters span approximately $28 \mathrm{~kb}$ and contain genes coding for the biosynthesis and export of the toxin. A putative insertion/excision site in the Australian Anabaena circinalis AWQCI $3 \mathrm{IC}$ was identified, and the organization and evolution of the gene clusters are discussed. A biosynthetic pathway leading to the formation of saxitoxin and its analogues in these organisms is proposed.

Conclusion: The PST biosynthesis gene cluster presents a mosaic structure, whereby genes have apparently transposed in segments of varying size, resulting in different gene arrangements in all three sxt clusters sequenced so far. The gene cluster organizational structure and sequence similarity seems to reflect the phylogeny of the producer organisms, indicating that the gene clusters have an ancient origin, or that their lateral transfer was also an ancient event. The knowledge we gain from the characterisation of the PST biosynthesis gene clusters, including the identity and sequence of the genes involved in the biosynthesis, may also afford the identification of these gene clusters in dinoflagellates, the cause of human mortalities and significant financial loss to the tourism and shellfish industries.
\end{abstract}




\section{Background}

Paralytic shellfish poisoning (PSP) is a syndrome acquired through the consumption of contaminated shellfish or drinking water. Its symptoms include numbness and ascending paralysis followed by respiratory arrest [1]. Toxicity is mediated by a group of toxins collectively referred to as paralytic shellfish toxins (PSTs) or saxitoxins (STX).

The global occurrence of PSTs coupled with their chemical stability and high toxicity, presents a formidable problem for marine and freshwater regulating bodies, while detrimentally affecting the health of humans and animal worldwide $[2,3]$. STX and its analogues are potent neurotoxic alkaloids. PSTs have been shown to specifically block voltage-gated sodium and calcium channels $[4,5]$, and prolong the gating of potassium channels in heart cells [6]. This mechanism prevents the conduction of a neural action potentials, paralysing the victim, and has also been shown to exhibit a cardio-depressory effect [1]. Additionally, the globally observed abundance of PST producing microorganisms, specifically dinoflagellates, cause substantial economic damage to the fishing industry, mainly due to closure of fisheries affected by PST producing blooms, as well as the regulatory requirement for expensive toxin monitoring programs [7].

The parent compound of PSTs, STX, is a tricyclic perhydropurine alkaloid, which can be substituted at various positions, leading to more than 30 naturally occurring STX analogues [8-13] (Figure 1). The synthesis of PSTs has been reported in freshwater and marine organisms alike, spaning two kingdoms of life. The marine microorganisms, dinoflagellates, belonging to the genera Alexandrium, Pyrodinium and Gymnodinium have been reported to produce PSTs [14-16]. In freshwater systems several filamentous species of cyanobacteria, such as Anabaena, Aphanizomenon, Cylindrospermopsis and Lyngbya are also known to produce PSTs [17-20].

The occurrence of a neurotoxin, originally termed aphatoxin, from Aphanizomenon flos-aquae was first demonstrated by Sawyer et al. [21], where a copper sulfate treatment of a cyanobacterial bloom led to the death of six tonnes of fish in Kezar Lake, New Hampshire. PST production was later confirmed in the cultured strain Aphanizomenon flos-aquae NH-5, isolated from a small pond near Durham, New Hampshire. This study identified the presence of saxitoxin (STX) and neosaxitoxin (neoSTX), together with further unidentified toxic fractions [17]. Li et al. [22] re-evaluated the morphological based taxonomy of the toxic Aphanizomenon flos-aquae NH-5 strain. They compared the 16S rRNA gene sequences and morphology of this strain with six other strains of Aphanizomenon flos-aquae and reclassified it as Aphanizomenon sp. NH5. According to morphological and gene sequence data, four of the investigated strains of Aphanizomenon flos- aquae, that have not been shown to produce toxins, are grouped together in the phylogenetic tree and were delineated from the branch represented by the two known toxin-producing Aphanizomenon isolates. Furthermore, $\mathrm{Li}$ et al. [23] reclassified the paralytic shellfish toxin-producing Aphanizomenon flos-aquae LMECYA 31 as Aphanizomenon issatschenkoi based on morphological and 16S rRNA gene sequence characteristics. The Aphanizomenon strains in this study formed a monophyletic cluster with three other species designations; the fascicle-forming Aphanizomenon flos-aquae, Aphanizomenon gracile strains having solitary trichomes, and Aphanizomenon issatschenkoi strains characterized by solitary trichomes that have tapered ends. More recently, a different Aph. flos-aquae strain from Portugal has been isolated and shown to produce the PSTs, STX, neosaxitoxin (neoSTX), gonyautoxin 5 (GTX5), gonyautoxin 6 (GTX6) and decarbamoyl saxitoxin (dcSTX) [3].

Similarly, Anabaena circinalis is a common toxic bloomforming planktonic freshwater cyanobacterium with a global distribution and an unusual geographical segregation of toxin production [24]. Australian reports of neurotoxic cyanobacterial blooms have principally implicated A. circinalis as the toxin producing species. In 1991 a neurotoxic bloom of A. circinalis covering over $1000 \mathrm{~km}$ of the Darling River in Australia, reportedly with concentrations of up to 500,000 cells per millilitre, was the cause of cattle mortality $[25,26]$. A following comprehensive study of the Murray-Darling basin in 1994 implicated A. circinalis in all neurotoxic blooms in Australia, and also showed $A$. circinalis to produce PSTs, mainly STX, GTX2/3 and dcGTX2/3 $[18,27]$. A detailed chemical analysis of the cultured strain A. circinalis AWQC131C revealed the presence of STX, GTX2/3, C1/2, dcSTX and dcGTX2/3 [28].

We have recently proposed a putative STX biosynthesis gene cluster in Cylindrospermopsis raciborskii $\mathrm{T} 3$ [29]. The putative STX biosynthesis gene cluster $(s x t)$ in C. raciborskii T3 spans approximately $36 \mathrm{~kb}$, and encodes genes involved in the biosynthesis, regulation and export of PSTs (Figure 2). Some of the genes identified in the C. raciborskii $\mathrm{T} 3$ gene cluster have not have been assigned a function due to their low level of structural homology to proteins in available databases. These genes may therefore represent novel enzyme families. Since C. raciborskii T3 is not genetically transformable, mutagenesis of the sxt cluster was not possible. The choice of identifying and characterizing the two novel putative PST biosynthesis gene clusters in Anabaena and Aphanizomenon was principally motivated by the detrimental effect the producer organisms have on water quality and public health. Furthermore, comparative analysis of the differences identified in toxin production, that is, the lack of neoSTX and all other N1-hydroxylated PSTs in A. circinalis AWQC131C, may provide further insights into the PST biosynthetic machin- 


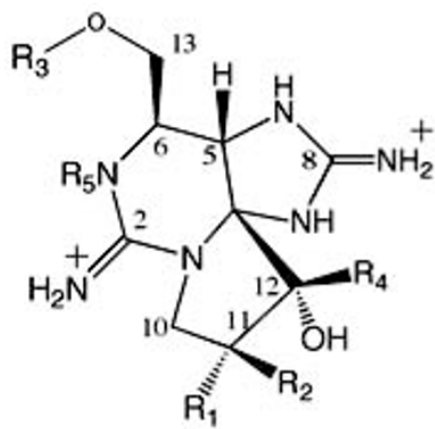

\begin{tabular}{|c|c|c|c|c|c|}
\hline PST & RI & R2 & R3 & R4 & R5 \\
\hline STX & $\mathrm{H}$ & $\mathrm{H}$ & $\mathrm{CONH}_{2}$ & $\mathrm{OH}$ & $\mathrm{H}$ \\
\hline neosTX ${ }^{b}$ & $\mathrm{H}$ & $\mathrm{H}$ & $\mathrm{CONH}_{2}$ & $\mathrm{OH}$ & $\mathrm{OH}$ \\
\hline GTXI & $\mathrm{H}$ & $\mathrm{OSO}_{3}^{-}$ & $\mathrm{CONH}_{2}$ & $\mathrm{OH}$ & $\mathrm{OH}$ \\
\hline GTX2 " & $\mathrm{H}$ & $\mathrm{OSO}_{3}^{-}$ & $\mathrm{CONH}_{2}$ & $\mathrm{OH}$ & $\mathrm{H}$ \\
\hline $\mathrm{GTX}^{3}{ }^{a}$ & $\mathrm{OSO}_{3}{ }^{-}$ & $\mathrm{H}$ & $\mathrm{CONH}_{2}$ & $\mathrm{OH}$ & $\mathrm{H}$ \\
\hline GTX4 & $\mathrm{OSO}_{3}{ }^{-}$ & $\mathrm{H}$ & $\mathrm{CONH}_{2}$ & $\mathrm{OH}$ & $\mathrm{OH}$ \\
\hline GTX5 (B1) & $\mathrm{H}$ & $\mathrm{H}$ & $\mathrm{CONHSO}_{3}{ }^{-}$ & $\mathrm{OH}$ & $\mathrm{H}$ \\
\hline GTX6 (B2) & $\mathrm{H}$ & $\mathrm{H}$ & $\mathrm{CONHSO}_{3}{ }^{-}$ & $\mathrm{OH}$ & $\mathrm{OH}$ \\
\hline $\mathrm{Cl}^{2}$ & $\mathrm{H}$ & $\mathrm{OSO}_{3}{ }^{\circ}$ & $\mathrm{CONHSO}_{3}{ }^{-}$ & $\mathrm{OH}$ & $\mathrm{H}$ \\
\hline $\mathrm{C} 2{ }^{2}$ & $\mathrm{OSO}_{3}{ }^{-}$ & $\mathrm{H}$ & $\mathrm{CONHSO}_{3}{ }^{-}$ & $\mathrm{OH}$ & $\mathrm{H}$ \\
\hline $\mathrm{C} 3$ & $\mathrm{H}$ & $\mathrm{OSO}_{3}{ }^{\circ}$ & $\mathrm{CONHSO}_{3}{ }^{-}$ & $\mathrm{OH}$ & $\mathrm{OH}$ \\
\hline C4 & $\mathrm{OSO}_{3}{ }^{-}$ & $\mathrm{H}$ & $\mathrm{CONHSO}_{3}{ }^{-}$ & $\mathrm{OH}$ & $\mathrm{OH}$ \\
\hline deSTX & $\mathrm{H}$ & $\mathrm{H}$ & H & $\mathrm{OH}$ & $\mathrm{H}$ \\
\hline deneoSTX & $\mathrm{H}$ & $\mathrm{H}$ & H & $\mathrm{OH}$ & $\mathrm{OH}$ \\
\hline dcGTXI & $\mathrm{H}$ & $\mathrm{OSO}_{3}{ }^{-}$ & H & $\mathrm{OH}$ & $\mathrm{OH}$ \\
\hline deGTX2 & $\mathrm{H}$ & $\mathrm{OSO}_{3}{ }^{-}$ & H & $\mathrm{OH}$ & $\mathrm{H}$ \\
\hline deGTX3 & $\mathrm{OSO}_{3}^{-}$ & H & H & $\mathrm{OH}$ & $\mathrm{H}$ \\
\hline dcGTX4 & $\mathrm{OSO}_{3}^{-}$ & $\mathrm{H}$ & H & $\mathrm{OH}$ & $\mathrm{OH}$ \\
\hline 1 & $\mathrm{H}$ & $\mathrm{OSO}_{3}{ }^{\circ}$ & $\mathrm{COCH}_{3}$ & $\mathrm{H}$ & $\mathrm{H}$ \\
\hline 2 & $\mathrm{H}$ & $\mathrm{OSO}_{3}{ }^{*}$ & $\mathrm{COCH}_{3}$ & $\mathrm{H}$ & $\mathrm{OH}$ \\
\hline 3 & $\mathrm{OSO}_{3}{ }^{\prime}$ & $\mathrm{H}$ & $\mathrm{COCH}_{3}$ & $\mathrm{H}$ & $\mathrm{OH}$ \\
\hline 4 & H & $\mathrm{H}$ & H & $\mathrm{H}$ & $\mathrm{H}$ \\
\hline 5 & $\mathrm{H}$ & $\mathrm{H}$ & $\mathrm{COCH}_{3}$ & $\mathrm{H}$ & $\mathrm{OH}$ \\
\hline 6 & $\mathrm{H}$ & $\mathrm{H}$ & $\mathrm{COCH}_{3}$ & $\mathrm{H}$ & $\mathrm{H}$ \\
\hline
\end{tabular}

\section{Figure I}

Chemical structure of the major paralytic shellfish toxins (PST). a PSTs identified in Anabaena circinalis AWQCI3IC, b PSTs identified in Aphanizomenon. sp. NH-5. STX, saxitoxin; GTX, gonyautoxin; dc, decarbamoyl.

ery $[17,28]$. The close taxonomic and phylogenetic relatedness of these two PST-producing organisms, also provides insights into the evolutionary history of the putative PST biosynthesis gene clusters, revealing whether they are of a common ancestor or laterally derived via horizontal gene transfer.

\section{Results and discussion Identification of PST gene clusters in A. circinalis AWQCI 3 IC and Aph. sp. NH-5}

The gene cluster putatively responsible for the biosynthesis of PSTs in the cyanobacterium C. raciborskii T3 has recently been characterized by our group [29]. In an attempt to identify the putative PST biosynthesis gene cluster analogs, from the PST producing organisms A. circinalis AWQC131C and Aph. sp. NH-5, a reverse genetic approach was employed. The primer pair nodF and nodR (Table 1) was used in a degenerate PCR, targeting conserved regions in carbamoyltransferases (sxtI), which are putatively involved in the transfer of a carbamoyl group from carbamoyl phosphate onto the free hydroxymethyl side chain of the saxitoxin precursor [29,30]. A single amplicon of about 900 bp in size was amplified using genomic DNA isolated from both $A$. circinalis AWQC131C and Aph. sp. NH-5. The degenerate PCR products were then cloned and clone libraries were constructed, in an attempt to identify all the carbamoyltrasferases in these PST producing organisms. Screening of these clone libraries revealed only one gene fragment in each of the libraries. BLAST similarity searches showed homology between these gene fragments and other carbamoyltransferases. The sxtI gene homologs identified in A. circinalis AWQC131C and Aph. sp. NH-5 were $90 \%$ and $91 \%$ identical in sequence to the sxtI gene from C. raciborskii $\mathrm{T} 3$, respectively, and were $97 \%$ identical among themselves (Table 2) [29]. These gene fragments were consequently good candidates for sxtI homologs, and therefore also PST biosynthesis genes in these cyanobacteria.

In order to obtain the DNA sequences of the entire putative PST biosynthesis gene clusters in both $A$. circinalis AWQC131C and Aph. sp. NH-5, a gene walking technique (known as pan-handle PCR) was employed [31]. Following numerous rounds of sequencing-out and gene-walking reactions from the putative sxtI homologues, the entire gene cluster in both organisms was identified, sequenced and characterized (Figure 2). The putative PST gene cluster in both organisms is of comparable size. The A. circinalis AWQC131C sxt gene cluster spans $29 \mathrm{~kb}$, flanked by a $\beta$-lactamase, a gene involved in antibiotic resistance, at the 5 ' end and a smf gene homolog, believed to be involved in DNA uptake at the 3 ' end (Figure 2). The Aph. sp. NH-5 sxt gene cluster is slightly smaller and covers $27.5 \mathrm{~kb}$. It is flanked on both sides by genes coding for photosynthesis machinery, at the 5 ' end by $p s b H$, a photosystem II reaction centre gene and at the 3 ' end by a prenyltransferase involved in the synthesis of ubiquinone (Figure 2).

\section{Characterisation of the PST biosynthesis gene clusters}

The major PSTs identified in Aph. sp. NH-5 are neoSTX and STX [17] and other toxic fractions that were not identified, although the methods used were not highly sensitive. While the major PSTs identified in A. circinalis AWQC131C were STX, GTX2/3, C1/2, dcSTX and dcGTX2/3 [28]. This observed difference in the toxin profiles is most probably the result of the different genetic backgrounds in these producer organisms, as modifica- 

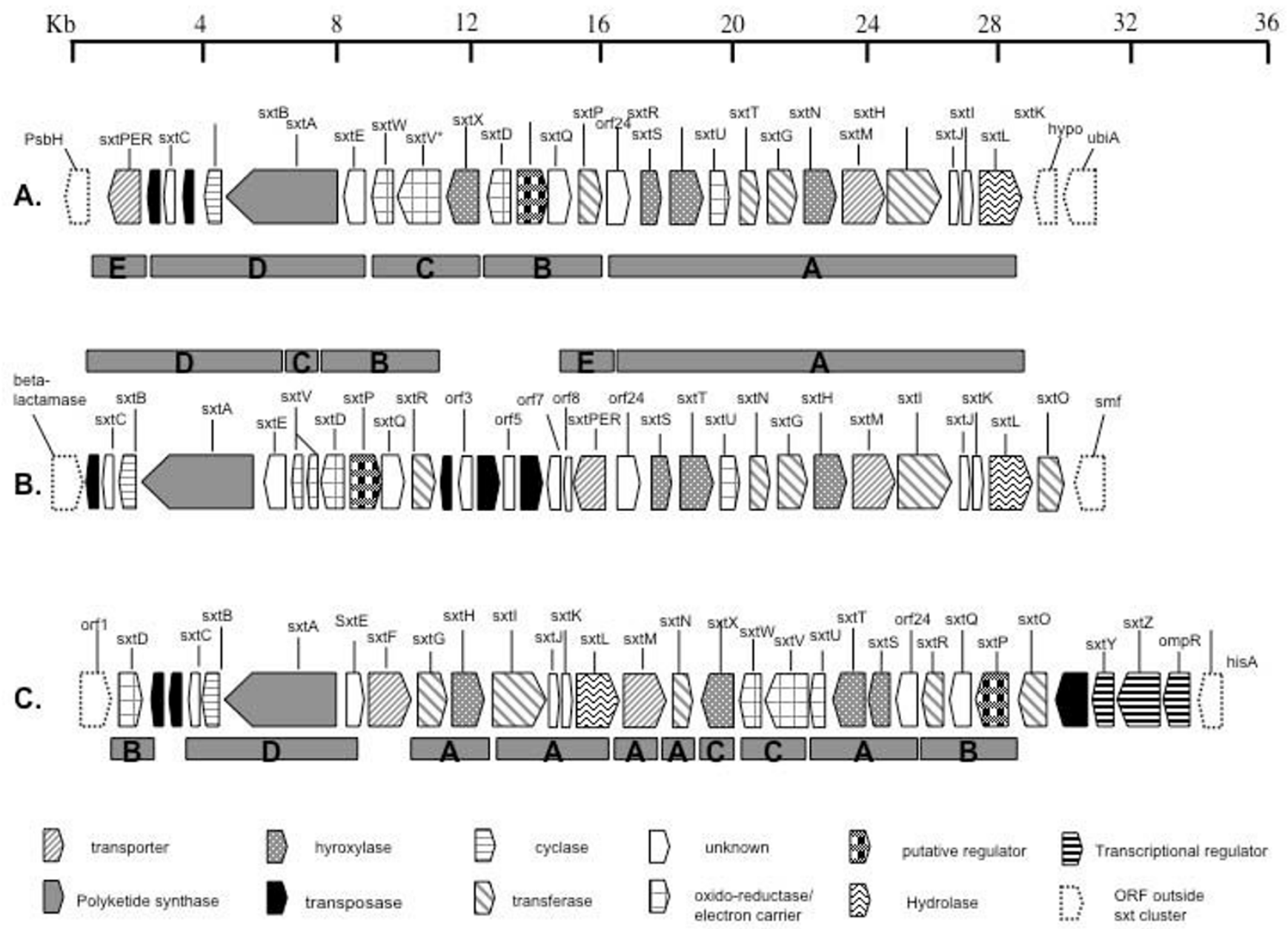

Figure 2

Structure of the paralytic shellfish toxin biosynthesis cluster identified in A. Aphanizomenon. sp. NH-5, B. Anabaena circinalis AWQCI3 I C, C. Cylindrospermopsis raciborskii T3. The gene cluster schematic for C. raciborskii T3 has been adapted from kellmann et al. 2008 [29]. Segments A-E denote cluster fragments homologous in the three strains. The scale indicates length in thousand base pairs. ompR, transcriptional regulator of ompR family.

tion reactions to the STX parent molecule, carried out by the sxt gene cluster tailoring enzymes, putatively result in the formation of the various PSTs.

Both gene clusters characterized in this study contain the same set of genes identified in the putative PST biosynthesis gene cluster (sxt) of C. raciborskii T3 with some exceptions (Table 2) [29]. Specifically, they do not contain the genes $s x t Y$, sxtZ and ompR, believed to be involved in signal transduction and the transcriptional regulation of PST production in C. raciborskii $\mathrm{T} 3$, and therefore might be regulated in a different manner, however it can not be completely excluded that these genes have diverged and transposed to a different locus in the genome. Furthermore, they do not contain the gene sxtF putatively involved in PST transport. Both the A. circinalis
AWQC131C and the Aph. sp. NH-5 PST gene clusters contain a gene, denoted sxtPER. Curiously, sxtPER, a gene most similar to members of the drug and metabolite transport family, has not been identified in the C. raciborskii T3 PST gene cluster.sxtPER might therefore fulfil a similar role to $s x t F$ in C. raciborskii $\mathrm{T} 3$ and is postulated to be involved in the transport of PSTs in Anabaena and Aphani-

Table I: PCR primer sequences used in this study

\begin{tabular}{llc}
\hline Name & Primer sequence (5'-3') & Reference \\
\hline NodF & ATGGGHYTRGCHCCHTAYGG & {$[29]$} \\
NodR & CCBCGYACRTTRAAKGABGTRTT & {$[29]$} \\
AnastartF & CGGGGGTATTTTTATTAGAC & This study \\
Ana30kbR & AGGGAATAGACACCGAAAGT & This study \\
\hline
\end{tabular}


zomenon. Interestingly, sxtPER has an evolutionary history apparently distinct from $s x t M$ and $s x t F$ and represents a different lineage, while $s x t F$ seems to have arisen by a gene duplication event of sxtM. The phylogeny, function and distribution of cyanobacterial MATE genes are addressed in a separate publication (Pengelly JJL, Mihali TK, Neilan BA: Identification, phylogeny and expression of novel members of the multi-drug and toxic compound extrusion (MATE) family from cyanobacteria, submitted).
Furthermore, the Aph. sp. NH-5 sxt gene cluster is missing a $s x t O$ homolog, an adenylylsulfate kinase. sxtO is present in the A. circinalis AWQC131C sxt gene cluster and the C. raciborskii $\mathrm{T} 3$ sxt gene cluster. sxtO is most similar to adenylylsulfate kinases that are involved in the formation of 5'-phosphoadenosine 3'-phosphosulfate (PAPS), which is the sulfate donor for PAPS dependant sulfotransferases (Table 2) [29]. The toxin profile of Aph. sp. NH-5 has not been fully characterized, however, it has been shown to

Table 2: Similarity and predicted function of PST biosynthesis genes

\begin{tabular}{|c|c|c|c|c|c|c|c|}
\hline Gene & $\begin{array}{l}\text { A. circinalis } \\
\text { AWQCI } 3 \text { IC } \\
\text { gene size (bp) }\end{array}$ & $\begin{array}{l}\text { A. circinalis } \\
\text { AWQCI3IC } \\
\text { identity to C. } \\
\text { raciborskii T3 }\end{array}$ & $\begin{array}{l}\text { Aph. sp. NH- } \\
5 \text { gene size } \\
\text { bp }\end{array}$ & $\begin{array}{l}\text { Aph. sp. NH-5 } \\
\text { identity to C. } \\
\text { raciborskii T3 }\end{array}$ & $\begin{array}{l}\text { Aph. sp. NH-5/A. } \\
\text { circinalis } \\
\text { AWQCI3IC } \\
\text { identity }\end{array}$ & $\begin{array}{l}\text { Closest BLAST } \\
\text { match }\end{array}$ & Putative function \\
\hline $\operatorname{sxtC}$ & 285 & $90 \%$ & 285 & $90 \%$ & $99 \%$ & $\begin{array}{l}\text { ABI75092.I SxtC } \\
\text { (354 bp) }\end{array}$ & Unknown \\
\hline sxtB & 978 & $87 \%$ & 969 & $88 \%$ & $97 \%$ & $A B I 75093.1$ SxtB & Cyclisation \\
\hline sxtA & 3705 & $90 \%$ & 3705 & $90 \%$ & $99 \%$ & ABI75094.I SxtA & $\begin{array}{l}\text { Loading of } A C P \text {, } \\
\text { methylation, ACP, } \\
\text { Claisen } \\
\text { condensation }\end{array}$ \\
\hline sxtE & 477 & $64 \%$ & 363 & $83 \%$ & $75 \%$ & ABI75095.I SxtE & Unknown \\
\hline sxtV & Disrupted & ---- & 1663 & $90 \%$ & ---- & SxtV ABI75I07.I & Inactive \\
\hline sxtD & 759 & $88 \%$ & 759 & $89 \%$ & $98 \%$ & SxtD ABI75089.I & Desaturation \\
\hline sxtP & 1449 & $53 \%$ & 1443 & $58 \%$ & $97 \%$ & SxtP ABI75II4.I & $\begin{array}{l}\text { Regulator/pilli } \\
\text { formation }\end{array}$ \\
\hline sxtQ & 777 & $91 \%$ & 777 & $90 \%$ & $98 \%$ & SxtQ ABI75II3.I & Unknown \\
\hline$s \times t R$ & 804 & $88 \%$ & 777 & $87 \%$ & $87 \%$ & SxtR ABI75II2.I & $\begin{array}{l}\text { Acyl-CoA N- } \\
\text { acyltransferase }\end{array}$ \\
\hline sxtPER & 957 & ----- & 1059 & ---- & $82 \%$ & $\begin{array}{l}\text { Nostoc punctiforme } \\
\text { PCC 73102 } \\
\text { ACC } 82015.1\end{array}$ & Transporter \\
\hline orf24 & 627 & $83 \%$ & 576 & $92 \%$ & $86 \%$ & Orf24 ABI75III.I & Unknown \\
\hline sxtS & 726 & $87 \%$ & 729 & $75 \%$ & $90 \%$ & sxtS ABI75II0.I & Ring formation \\
\hline sxtT & 1020 & $82 \%$ & 1020 & $86 \%$ & $95 \%$ & sxtT ABI75I09.I & C- 12 hydroxylation \\
\hline sxtU & 750 & $88 \%$ & 750 & $87 \%$ & $97 \%$ & sxtU ABI75I08.I & Reduction of C-I \\
\hline $\operatorname{sxt} \mathrm{N}$ & 870 & $86 \%$ & 846 & $89 \%$ & $92 \%$ & sxtN ABI75I 04.1 & Sulfotransfer \\
\hline sxtG & 1134 & $93 \%$ & 1134 & $94 \%$ & $98 \%$ & sxtG ACF94638.I & Amidinotransfer \\
\hline sxtH & 1020 & $84 \%$ & 1020 & $87 \%$ & $95 \%$ & sxtH ACF94646.I & C-12 hydroxylation \\
\hline sxtM & 1458 & $82 \%$ & 1458 & $76 \%$ & $92 \%$ & sxtM ABI75I03.I & Export of PSTs \\
\hline sxtl & 1839 & $90 \%$ & 1839 & $91 \%$ & $97 \%$ & sxtl ABI75099.I & Carbamoylation \\
\hline$s x t]$ & 405 & $82 \%$ & 405 & $82 \%$ & $98 \%$ & sxt] $A B \mid 75100.1$ & Unknown \\
\hline sxtK & 165 & $93 \%$ & 165 & $90 \%$ & $96 \%$ & sxtK ABI75I0I.I & Unknown \\
\hline sxtL & $128 \mid$ & $83 \%$ & 1278 & $85 \%$ & $92 \%$ & sxtL ABI75I02.I & Decarbamoylation \\
\hline sxtO & 570 & $12 \%$ & ----- & ---- & ---- & $\begin{array}{l}\text { Cyanothece sp. PCC } \\
8801 \text { adenylylsulfate } \\
\text { kinase } \\
\text { ZP_02939438.I }\end{array}$ & PAPS biosynthesis \\
\hline sxtW & ----- & ---- & 327 & $95 \%$ & ---- & sxtW ABI75I06.I & $\begin{array}{l}\text { Ferredoxin/ } \\
\text { electron carrier }\end{array}$ \\
\hline $\operatorname{sxtX}$ & ----- & ----- & 756 & $87 \%$ & ----- & sxtX ABI75I05.I & N-I hydroxylation \\
\hline orf3 & 302 & ----- & ----- & ---- & ---- & sxtN ABI75 I04.I & $\begin{array}{l}\text { Disrupted } \\
\text { sulfotransferase }\end{array}$ \\
\hline orf5 & 459 & ----- & ----- & ---- & ----- & sxtN ABI75I04.I & $\begin{array}{l}\text { Disrupted } \\
\text { sulfotransferase }\end{array}$ \\
\hline orf7 & 226 & ----- & ---- & ---- & ---- & sxtN ABI75 I04.I & $\begin{array}{l}\text { Disrupted } \\
\text { sulfotransferase }\end{array}$ \\
\hline orf8 & 98 & ----- & ----- & ----- & ---- & sxtW ABI75I06.I & $\begin{array}{l}\text { Disrupted } \\
\text { ferredoxin }\end{array}$ \\
\hline
\end{tabular}

The saxitoxin biosynthesis genes in Anabaena circinalis AWQCI $3 I C$ and Aphanizomenon sp. NH-5, their similarities and bioinformatically-deduced functions. Closest BLAST match column refers to both $A$. circinalis AWQCI3IC \&Aph. sp. NH-5, if present in both species. 
produce STX and neoSTX and possibly other unidentified toxic fractions [17]. It is therefore not possible to asses whether this strain actually produces sulfated PSTs. As adenylylsulfate kinases are not unique to the PST gene clusters, and are ubiquitous enzymes needed for all PAPS dependant sulfotransferases, it seems plausible that this genetic mutation could be complemented by an additional adenylylsulfate kinase elsewhere in the genome of Aph. sp. NH-5. Curiously, the sxtO homolog identified in A. circinalis AWQC131C sxt gene cluster has very low similarity to $s x t O$ identified in C. raciborskii $\mathrm{T} 3$ (Table 2), and is more similar to other cyanobacterial derived adenylylsulfate kinases. This observation further supports the idea that PST biosynthesis accessory genes may be complimented by gene homologs in the genome of the producer organism.

On the other hand, the A. circinalis AWQC131C putative PST biosynthesis gene cluster does not contain the tailoring gene sxt $X$, which is most similar to a cephalosporine hydroxylase, and presumably responsible for the hydroxylation of N-1 in STX, thereby converting STX to neoSTX (Figure 3). Hence, $s x t X$ is putatively involved in the formation of all the analogs containing a hydroxyl at N-1 (Figure 1). In accordance with this finding, $A$. circinalis AWQC131C does not produce any STX congeners that contain a hydroxyl at N-1. In contrast the Aph. sp. NH-5 sxt gene cluster does contain the tailoring enzyme gene $s x t X$, and correspondingly been shown to produce the $\mathrm{N}$ 1 hydroxylated analog neoSTX [17], further affirming its putative role in the PST biosynthesis gene cluster.

The A. circinalis AWQC131C sxt gene cluster does not contain the gene sxtW, which is present in the Aph. sp. NH-5 and the C. raciborskii $\mathrm{T} 3$ sxt gene clusters. sxt $W$ is most similar to a ferredoxin and is believed to be involved in electron transport, required for the hydroxylation of C-12 by the two ring-hydroxylating dioxygenases, encoded by sxtT and $s x t H$. Curiously, the A. circinalis AWQC131C sxt gene cluster contains a small (98 bp), disrupted ORF denoted orf8, with similarity to $s x t W$ and other ferredoxin genes (Table 2). Orf8 might therefore represent yet another fragment of a PST biosynthesis accessory gene that has been inactivated. It is plausible that an endogenous ferredoxin complements for its loss in A. circinalis AWQC131C, since homologs of ferredoxin (Accession no. Npun_R5178, Ava_5008) have been detected in several recently released cyanobacterial genomes, as evident from BLAST homology searches.

$s x t V$, a gene most similar to succinate dehydrogenases, originally identified in the C. raciborskii T3 PST gene cluster, is also believed to be involved in this electron transport mechanism. Only a fragmented part of this gene is present in the A. circinalis AWQC131C sxt gene cluster, while $s x t V$ in the Aph. sp. NH-5 sxt gene cluster contains a stop codon interrupting the ORF. It is therefore postulated that this gene is also complemented by another locus in the genome of these producer organisms or is not essential for PST biosynthesis.

Interestingly, the A. circinalis AWQC131C sxt gene cluster also contains partial transposase-like sequences, which interrupt a putative ORF and split it into 3 different fragmented partial ORFs, denoted orf3, orf5 and orf7 (Figure 2). This fragmented gene is partially similar to sxtN, homologs of which are present in the A. circinalis AWQC131C and Aph. sp. NH-5 sxt gene clusters, and putatively involved in the sulfation of STX and its derivative [29]. Due to its fragmentation and short coding sequence we were unable to assign a putative role for this gene, but it is assumed to be inactive.

\section{Structural organization}

The organization of genes in the, A. circinalis AWQC131C and Aph. sp. NH-5 sxt gene clusters, is very conserved, and has less common features with the organization of the $C$. raciborskii T3 sxt cluster (Figure 2). As depicted in Figure 2, the putative PST biosynthesis gene cluster can be divided into five segments of coding DNA, denoted as A-E. The A. circinalis AWQC131C sxt gene cluster contains three truncated ORFs (orf 3, 5 and 7) intersected by transposases, however, these are absent from the Aph. sp. NH-5 sxt gene cluster. In the Aph. sp. NH-5 sxt gene cluster, segment C contains the genes sxt $X, s x t V$ and $s x t W$, whereas in the $A$. circinalis AWQC131C sxt gene cluster most of segment C is missing, only a fragmented section of $s x t V$ is retained. Furthermore, in the A. circinalis AWQC131C putative PST biosynthesis gene cluster, segment $\mathrm{E}$ is adjacent to segment A, whereas in Aph. sp. NH-5 segment $\mathrm{E}$ is connected to segment D (Figure 2). Therefore, it seems plausible to assume that the A. circinalis AWQC131C sxt gene cluster has had at least two DNA recombination events as compared to the Aph. sp. NH-5 sxt gene cluster, with one event causing the truncation of segment $\mathrm{C}$, thereby losing the genes $s x t X, s x t V$ and $s x t W$. The other recombination event would have involved segment $\mathrm{E}$, which contains the gene denoted sxtPER, to relocate from its 5' position in Aph. sp. $\mathrm{NH}-5$ to the central region of the gene cluster in A. circinalis AWQC131C (Figure 2).

\section{Biosynthesis of PST congeners}

A detailed description of the proposed biosynthesis of the STX parent molecule has recently been published by our group [29]. Briefly, biosynthesis is initiated with SxtA, which contains 4 catalytic domains (Table 2, Figure 3 step 1-2). A methyltransferase domain (sxtA1), a GNAT domain (sxtA2) (loading of acyl carrier protein), an acyl carrier protein (ACP) domain (sxtA3) and an AONS domain (sxtA4) (which acts as a condensation domain). 

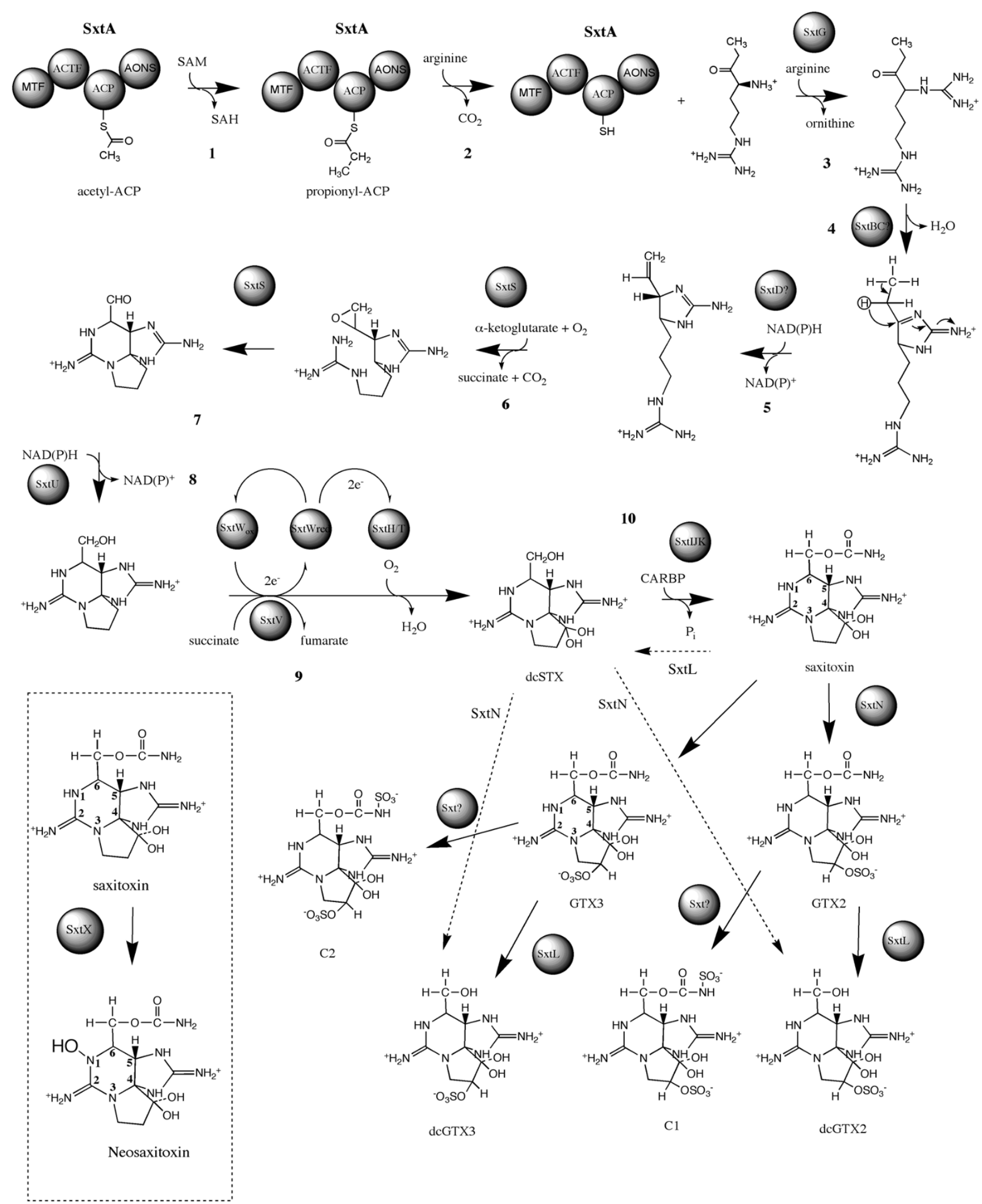

9

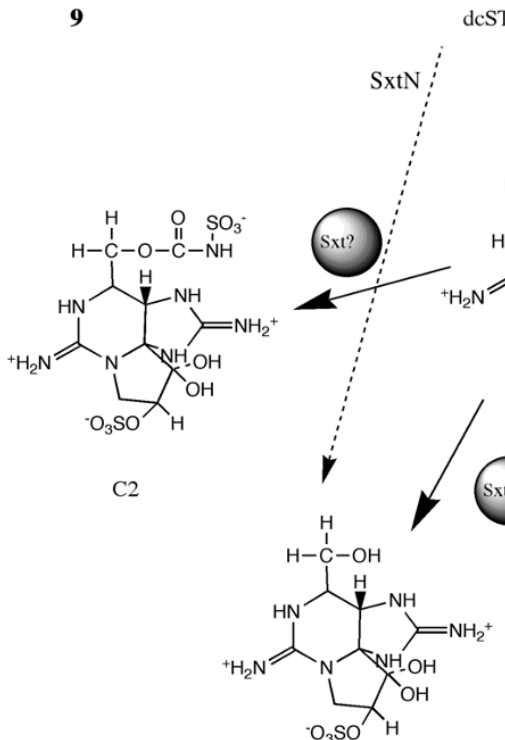

dcGTX3
10

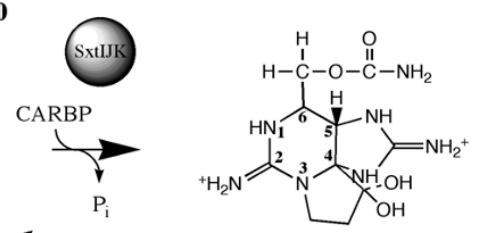

SxtL

CSTX

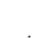

saxitoxin
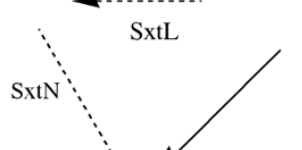
The predicted reaction sequence of SxtA, is the loading of the ACP (SxtA3) with acetate from acetyl-CoA by sxtA2, followed by the SxtA1-catalysed methylation of acetyl$\mathrm{ACP}$, converting it to propionyl-ACP. The class II aminotransferase domain (AONS), SxtA4, then performs a Claisen-condensation between propionyl-ACP and arginine. The product of SxtA is thus 4-amino-3-oxo-guanidinoheptane. The next step (Figure 3 step 3 ) is carried out by $S x t G$, an amidinotransferase that transfers an amidino group from arginine onto the product of SxtA, producing 4,7-diguanidino-3-oxoheptane. This compound is then condensed via SxtB, which is most similar to a cytidine deaminase, in a retro-aldol-like condensation (Figure 3 step 4) and the first heterocycle is formed. The following step (Figure 3 step 5) involves SxtD a desaturase, which introduces a double bond between $\mathrm{C}-1$ and $\mathrm{C}$ 5 resulting in the 1,2-H shift between C-5 and C-6. SxtS a 2-oxoglutarate-dependent (2OG) dioxygenase, then performs the consecutive epoxidation of the new double bond, and opening of the epoxide to an aldehyde with concomitant bicyclisation (Figure 3 steps 6-7). The dehydrogenase SxtU then reduces the terminal aldehyde group of the STX precursor (Figure 3 step 8). Thereafter (Figure 3 step 9), SxtH and SxtT, each coding a terminal oxygenase subunit of bacterial phenyl-propionate and related ringhydroxylating dioxygenases, catalyse the consecutive hydroxylation of C-12, forming dcSTX. Thereafter, SxtI in conjunction with SxtJ and SxtK catalyse a carbamoyltrasfer from carbamoylphosphate onto the free hydroxyl at C-13, forming saxitoxin (STX).

Subsequently, tailoring reactions catalyse the formation of the PST analogues, which are derivatives of the parent molecule STX. One of the most potent STX derivatives is the N-1 hydroxylated saxitoxin analogue neoSTX. As previously mentioned, SxtX has been predicted to be involved in the N-1 hydroxylation of saxitoxin [29]. Therefore we postulate that SxtX, which is not encoded in the A. circinalis AWQC131C PST biosynthesis gene cluster, carries out the conversion of STX to neoSTX (Figure 3). A. circinalis AWQC131C is known to produce $\mathrm{N}-21$ and O22 sulfated STX analogues (GTX2/3, C1/2, dcGTX2/3). The activity of two PAPS dependent sulfotransferases, which were specific for the N-21 of STX and GTX-3/2, and O-22 of 11-hydroxy STX, respectively, have been described from the PSP toxin-producing dinoflagellate Gymnodinium catenatum, although no protein sequence information was obtained due to instability of the enzyme and low yield [32,33]. Both putative PST biosynthesis gene clusters identified in this study contain a gene denoted $\operatorname{sxtN}$, which is most similar to estrogen sulfotransferase and putatively responsible for the sulfation of STX. Therefore, the protein encoded by $\operatorname{sxtN}$, is postulated to be responsible for the sulfation of STX at O-22 resulting in the formation of GTX2 and GTX3 (Figure 3).
Alternatively SxtN could sulfate N-21 of STX resulting in the formation of $\mathrm{C} 1$ and $\mathrm{C} 2$. It is further possible that the enzyme catalyses both reactions, or that a sulfotransferase not encoded in the PST biosynthesis gene cluster is involved. Whether the product of this gene sulfates $\mathrm{O}-22$ or N-21 of STX could not be determined at this point, and will require heterologous expression of the enzyme to determine its natural substrate specificities. dcSTX derivatives are postulated to result from the hydrolytic cleavage of carbamoylated STXs. The candidate enzyme encoded by $s x t L$, harbouring homology to GDSL-lipases, has been proposed to catalyse this cleavage [29]. SxtL would therefore catalyse the formation of dcGTX2/3 from GTX2/3, and putatively convert STX to dcSTX (Figure 3 ). The exact sequence of reactions is not clear at this point, as there is need for heterologous expression of each of these tailoring enzymes and their substrate specificities have to be confirmed experimentally.

\section{Phylogeny of the PST biosynthesis genes}

It is interesting to note that the organization of the putative PST gene clusters in A. circinalis AWQC131C and Aph. sp. NH-5 are more similar to each other, than to the organization in the recently identified putative PST gene cluster in C. raciborskii T3 (Figure 2). Furthermore, the A. circinalis AWQC131C and Aph. sp. NH-5 sxt genes show overall greater sequence similarity to each other than to the recently identified sxt genes in C. raciborskii T3 (Table 2). In an attempt to reconstruct the taxonomic phylogeny of the PST producing cyanobacteria $A$. circinalis AWQC131C, Aph. sp. NH-5, C. raciborskii T3 and L. wollei, a phylogenetic approach was used. 16S rRNA gene sequences for the PST-producing and non-producing cyanobacteria were retrieved from GenBank (Table 3). An alignment of these sequences was created and a phylogenetic tree based on a 685 bp segment of the 16S rRNA gene was reconstructed. As evident from the phylogenetic tree (Figure 4), A. circinalis AWQC131C and Aph. sp. NH5 form a supported clade together with the (non-toxic) $A$. circinalis AWQC310F (64\% bs) and are more closely related to each other than to C. raciborskii T3. Consequently, the topological organization of the PST biosynthesis gene cluster is reflected by the phylogeny of the producer organism, and they therefore most likely have a paralleled evolution.

Australian isolates of A. circinalis have been shown to be phylogenetically related, forming two distinct branches [24]. Furthermore, genetic screening has shown that only toxic isolates contain the putative genes for PST biosynthesis [29]. An attempt was made to identify the insertion/ excision point of the putative PST gene cluster in the Australian A. circinalis isolates. PCR primers AnastartF and Ana30kbR were designed based on the sequences obtained from A. circinalis AWQC131C (Table 1), as strain 
representative of the PST-producing lineage. These primers were designed within the ORF of the $\beta$-lactamase at the $5^{\prime}$ end, and smf at the $3^{\prime}$ end of the PST gene cluster in A. circinalis AWQC131C (Figure 5). A PCR reaction with this primer set was performed using genomic DNA isolated from the non-toxic $A$. circinalis $310 \mathrm{~F}$ strain belonging to the non-PST producing clade, and the PST-producing $A$. circinalis AWQC131C. The PCR resulted in the amplification of a $1.6 \mathrm{~kb}$ segment of DNA from A. circinalis $310 \mathrm{~F}$, whereas genomic DNA from A. circinalis AWQC131C did not yield a product. The predicted distance between the primer set in A. circinalis AWQC131C genomic DNA was over $29 \mathrm{~Kb}$ and therefore an amplicon was not expected using the conditions described. Sequencing followed by bioinformatic analysis of the $1.6 \mathrm{~kb}$ amplicon from $A$. circinalis 310F revealed two ORFs, one at the 5' end that was similar to a $\beta$-lactamase, and another at the 3 ' end similar to a smf gene, both homologous to the genes identified on either ends of the putative PST biosynthesis gene cluster in A. circinalis AWQC131C. A closer analysis of the A. circinalis $310 \mathrm{~F}$ amplified region revealed the presence of four direct repeats of the sequence TTCCCTG within the intragenic spacer identified between the two flanking ORFs (Figure 5). Insertion sites which are targeted by a transposon are usually innocuous and do not contain repeats, however, the presence of direct repeats is indicative of an excision event that has followed the insertion of a transposon [34]. Further examination of the non-coding regions flanking the PST biosynthesis gene cluster in $A$. circinalis AWQC131C revealed a relic inverted repeat of the sequence GGCTATCAATTCAGAT on either side of the PST biosynthesis gene cluster that could also indicate a past transposition event. The combination of these findings supports the theory that the non-toxic A. circinalis strains have lost the putative PST biosynthesis gene cluster during an excision event. Together with the observation that the organization of the putative PST biosynthesis gene clusters resembles the phylogeny of the producer organisms, as well as the fact that A. circinalis AWQC131C and Aph. sp. NH-5 PST genes are overall more similar to each other than to the C. raciborskii T3 PST genes (Table 2 ), might imply that the sxt gene cluster is of ancient origin. Therefore, the sporadic distribution of PST biosynthesis throughout phylogeny could be explained by the loss of function in non-toxic strains, rather than the acquisition of one or more genes during more recent horizontal transfer in PST producing toxic strains. A similar evolutionary history has recently been proposed for the sporadic distribution of another cyanobacterial toxin biosynthesis gene cluster encoding microcystin synthetase [35].

\section{Conclusion}

Here we have described the identification, annotation and characterisation of the putative PST biosynthesis gene clusters in A. circinalis AWQC131C and Aph. sp. NH-5. The
Table 3: I6S rDNA sequences

\begin{tabular}{lll}
\hline Strain & Gene & Accession no. \\
\hline Anabaena circinalis AWQCI3IC & I6S rDNA & $\underline{\text { AF247589 }}$ \\
Anabaena circinalis AWQC3IOF & I6S rDNA & $\underline{\text { AF247579 }}$ \\
Aphanizomenon sp. NH-5 & I6S rDNA & $\underline{\text { AF425995 }}$ \\
Anabaena/Nostoc sp. PCC7I20 & I6S rDNA & $\underline{\text { NC 003272 }}$ \\
Cylindrospermopsis raciborskii T3 & I6S rDNA & EU439566 \\
Lyngbya wollei & I6S rDNA & $\underline{\text { EU603708 }}$ \\
Arthrospira platensis & I6S rDNA & $\underline{\text { EU427543 }}$ \\
Synechocystis sp. PCC6803 & I6S rDNA & BA000022 \\
Microcystis aeruginosa PCC7806 & I6S rDNA & $\underline{\text { MAU03402 }}$ \\
Thermosynechococcus elongatus BP-I & I6S rDNA & $\underline{\text { BA000039 }}$ \\
\hline
\end{tabular}

$16 \mathrm{~S}$ rDNA sequences used in this study and their corresponding accession numbers.

putative PST biosynthesis gene cluster presents a mosaic structure, whereby genes have apparently transposed in segments of varying size, resulting in different gene arrangements in all three sxt clusters sequenced so far. This gene cluster arrangement is in agreement with a mobile genetic element, further supported by the identification of multiple transposase like sequences in other recently characterized cyanobacterial toxin and secondary metabolite gene clusters $[31,36,37]$. The putative point of insertion/ excision of the sxt gene cluster in Australian isolates of $A$. circinalis was also identified. The gene cluster organizational structure and gene sequence identity seem to reflect the phylogeny of the producer organisms, indicating that the gene clusters might have an ancient origin, or that their lateral transfer was also an ancient event. The further sequencing and characterisation of cyanobacterial PST biosynthesis gene clusters in different producer organisms, with different toxin profiles, may provide new insights into the biosynthetic machinery and the enzymes involved at each step. The availability of more putative PST biosynthesis gene sequences from different producer organisms will also enable the better monitoring of algal blooms by water authorities, including the use of PCRbased early warning systems. Future studies into the transcriptional control and physiological roles of the PSTs, furthering our ability to predict and prevent the formation of harmful algal blooms, is also possible given these gene sequences and associated regulatory regions. The knowledge we gain from the characterisation of the PST biosynthesis gene clusters, including the identity and sequence of the genes involved in the biosynthesis, may also afford the identification of these gene cluster in dinoflagellates, the cause of human mortalities and significant financial loss to the tourism and shellfish industries.

\section{Methods Cyanobacterial strains}

A. circinalis AWQC131C and Anabaena circinalis 310F [24] were grown in Jaworski medium [38] in static batch culture at $26^{\circ} \mathrm{C}$ under continuous illumination $(10 \mu \mathrm{mol} \mathrm{m}-$ 


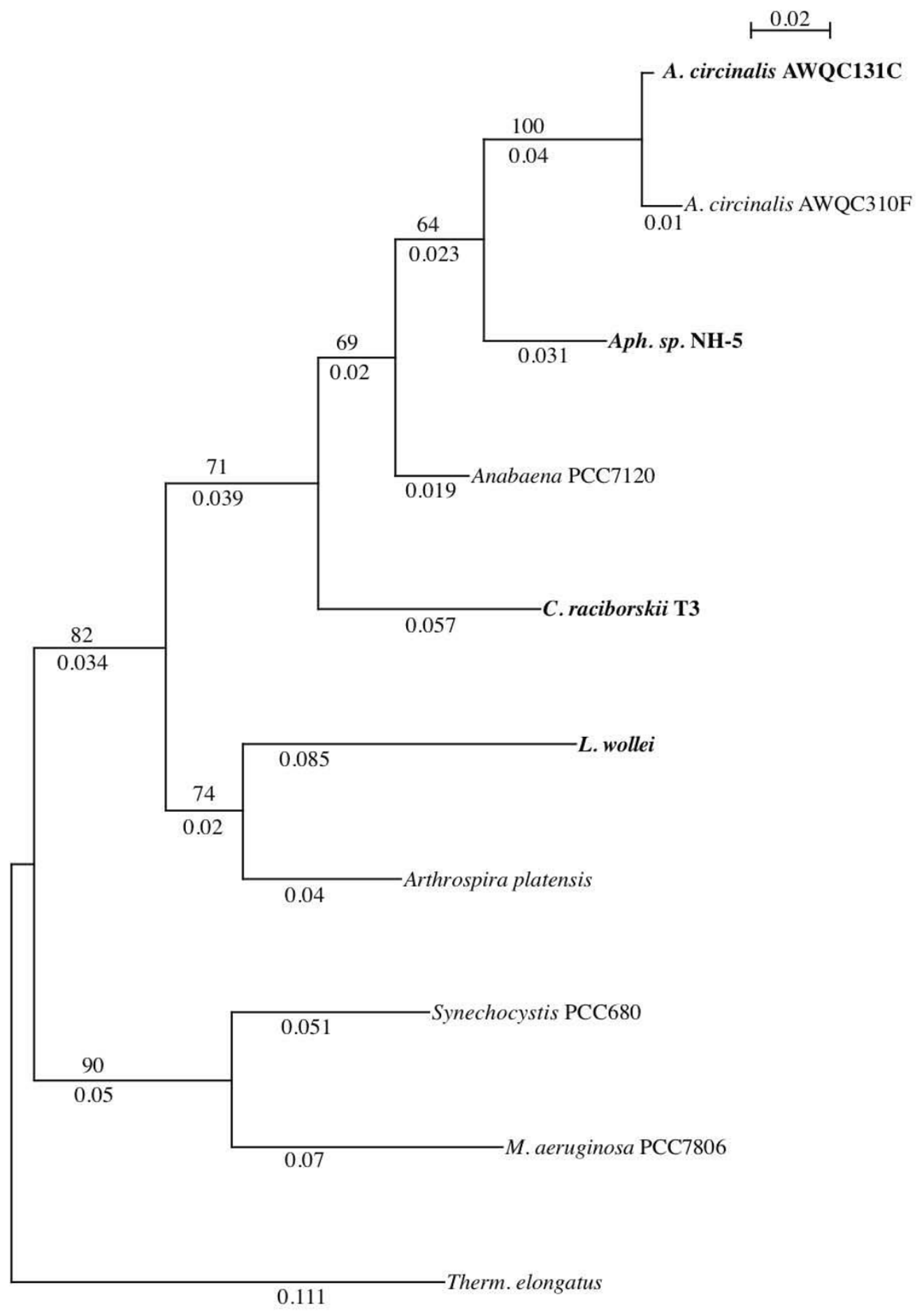

\section{Figure 4}

Phylogenetic tree of the 685 bp partial I6S rRNA gene from saxitoxin-producing cyanobateria. Anabaena circinalis AWQCI 3 IC and Aphanizomenon sp. NH-5 show highest similarity to each other compared to C. raciborskii T3 or L. wollei. Bootstrap confidence levels are indicated on top of each branch. Branch lengths are indicated below (nucleotide substitutions per 100 character positions). Trees were reconstructed using PhyML using a GTR+G model with I000 bootstrap replicas. Bold type indicates known PST producers. 


\section{A. circinalis $310 \mathrm{~F}$}

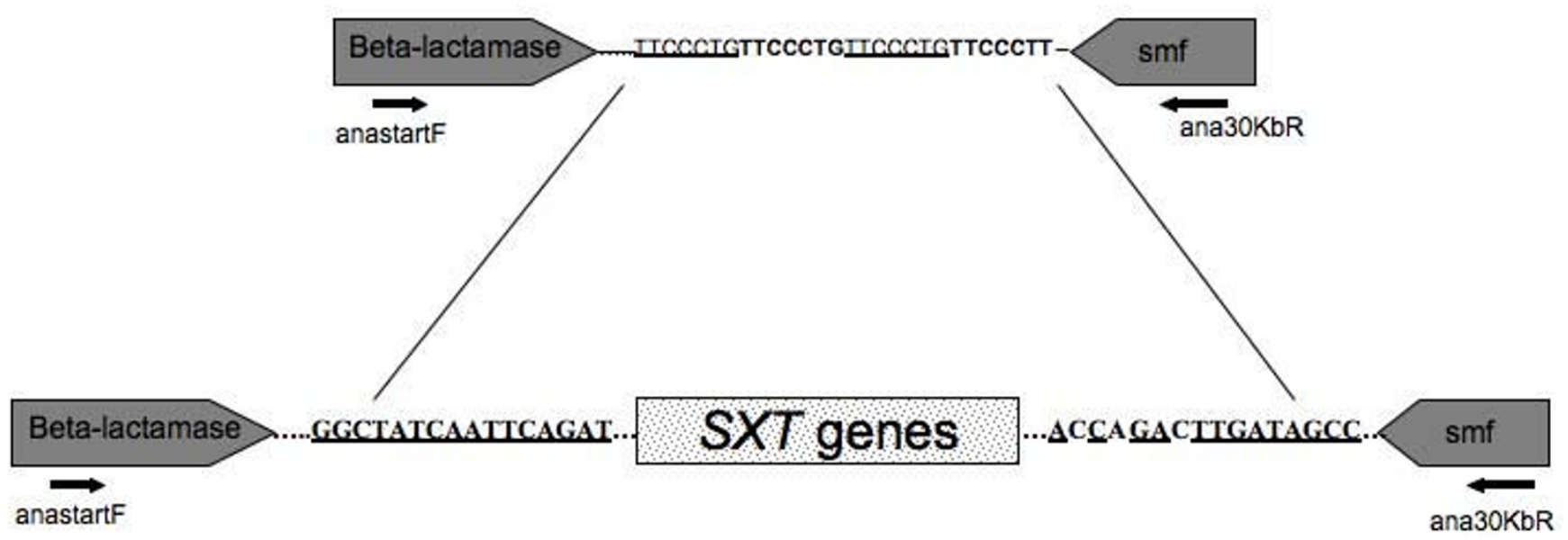

\section{A. circinalis AWQC131C}

\section{Figure 5}

Putative insertion/excision site of the paralytic shellfish toxin gene cluster, in Australian Anabaena circinalis strains. Diagram not to scale. See text for details.

$\left.{ }^{2} \mathrm{~s}^{-1}\right)$, Aph. sp. NH-5 and L. wollei freeze-dried cultures were kindly supplied by W. W. Carmichael $[17,19]$.

\section{DNA extraction}

Total genomic DNA was extracted from cyanobacterial cells using the Mo Bio PowerPlant DNA isolation kit (Carlsbad, CA) in accordance with the manufacturers instructions. Genomic DNA was stored at $-20^{\circ} \mathrm{C}$.

\section{PCR}

Insertion/excision point PCR was carried out using the primer set AnastartF and Ana30kbR (Table 1), and performed in $20 \mu \mathrm{l}$ reaction volumes containing $1 \times$ Taq polymerase buffer, $2.5 \mathrm{mM} \mathrm{MgCl}_{2}, 0.2 \mathrm{mM}$ deoxynucleotide triphosphates, $10 \mathrm{pmol}$ each of the forward and reverse primers, $50 \mathrm{ng}$ genomic DNA and $0.2 \mathrm{U}$ of Taq polymerase (Fisher Biotech, Australia). Thermal cycling was performed in a GeneAmp PCR System 2400 Thermal cycler (Perkin Elmer Corporation, Norwalk, CT). Cycling began with a denaturing step at $94^{\circ} \mathrm{C}$ for 4 min followed by 30 cycles of denaturation at $94^{\circ} \mathrm{C}$ for $10 \mathrm{~s}$, primer annealing at $55^{\circ} \mathrm{C}$ for $25 \mathrm{~s}$ and a DNA strand extension at $72^{\circ} \mathrm{C}$ for $2 \mathrm{~min}$. Amplification was completed by a final extension step at $72^{\circ} \mathrm{C}$ for $7 \mathrm{~min}$.

\section{Degenerate PCR}

Degenerate PCR primers targeting the carbamoyltransferase sxtI used in this study, nodF and nodR (Table 1), were designed ex-silico from sequence alignments using ClustalX [39]. Degenerate PCR was performed in $20 \mu \mathrm{l}$ reaction volumes containing $1 \times$ Taq polymerase buffer, $2.5 \mathrm{mM} \mathrm{MgCl}_{2}, 0.2 \mathrm{mM}$ deoxynucleotide triphosphates, $25 \mathrm{pmol}$ each of the forward and reverse primers, $50 \mathrm{ng}$ of genomic DNA and $0.2 \mathrm{U}$ of Taq polymerase (Fisher Biotech, Australia). Thermal cycling was performed in a GeneAmp PCR System 2400 Thermal cycler (Perkin Elmer Corporation, Norwalk, CT). Cycling began with a denaturing step at $94^{\circ} \mathrm{C}$ for 4 min followed by 35 cycles of denaturation at $94^{\circ} \mathrm{C}$ for $10 \mathrm{~s}$, primer annealing at $50^{\circ} \mathrm{C}$ for $30 \mathrm{~s}$ and a DNA strand extension at $72^{\circ} \mathrm{C}$ for $45 \mathrm{~s}$. Amplification was completed by a final extension step at $72{ }^{\circ} \mathrm{C}$ for $5 \mathrm{~min}$.

\section{Gene walking}

The sequence of unknown regions that were flanking candidate genes was determined by an adaptor-mediated (Pan-handle) PCR method [40] that was modified as previously described [31]. Short adaptor DNA was ligated to digested genomic DNA, and a specific genomic outwardfacing primer in combination with an adaptor primer was then used to amplify the unknown regions of the genome. Twenty picomoles of $\mathrm{T} 7$ adaptor were added to each reaction mixture, containing $1 \mu \mathrm{g}$ of genomic DNA, $10 \mathrm{U}$ of blunt-ended restriction enzyme, and $5 \mathrm{U}$ of $\mathrm{T} 4$ ligase (Promega) in $1 \times$ One Phor All buffer (Amersham/Pharmacia). The one-step digestion and ligation reaction mix- 
ture was incubated at room temperature overnight. The single-stranded end of the adaptor was blocked in a solution containing $1 \times$ PCR buffer (Fischer Biotech), $4 \mathrm{mM}$ $\mathrm{MgCl}_{2}$, and $12.5 \mu \mathrm{M}$ ddNTP with $1 \mathrm{U}$ of Taq DNA polymerase (Fischer Biotech). Thermal cycling was performed in a PCR Sprint temperature cycling system machine (Hybaid Ltd) with an initial step at $70^{\circ} \mathrm{C}$ for 15 min followed by 10 cycles of DNA denaturation at $95^{\circ} \mathrm{C}$ for $10 \mathrm{~s}$, DNA reannealing at $40^{\circ} \mathrm{C}$ for $1 \mathrm{~min}$, and extension of the strand with ddNTP at $70^{\circ} \mathrm{C}$ for $1 \mathrm{~min}$. Following the PCR cycles, the reaction mixture was incubated with $1 \mathrm{U}$ of shrimp alkaline phosphatase (Boehringer Mannheim, Göttingen, Germany) at $37^{\circ} \mathrm{C}$ for $20 \mathrm{~min}$, and the enzyme was heat inactivated at $85^{\circ} \mathrm{C}$ for $5 \mathrm{~min}$.

The flanking region PCR mixture contained 1 to $2 \mu \mathrm{l}$ of adaptor-ligated DNA, $10 \mathrm{pmol}$ of adaptor primer, 10 pmol of a genome-specific oligonucleotide primer and $0.5 \mathrm{U}$ of a mixture of 10:1 Taq polymerase/PFU (Fischer Biotech, Australia). PCR cycling was performed as described above, with DNA strand extension at $72^{\circ} \mathrm{C}$ for $3 \mathrm{~min}$. In addition, the primer annealing temperature was decreased for the first 10 cycles, by $1^{\circ} \mathrm{C}$ at each cycle, from 65 to $55^{\circ} \mathrm{C}$, followed by primer annealing at $55^{\circ} \mathrm{C}$ for a further 25 cycles.

\section{Agarose gel electrophoresis}

Amplified DNA was separated by gel electrophoresis with $1-2 \%$ agarose in TAE buffer $(40 \mathrm{mM}$ Tris-acetate, $1 \mathrm{mM}$ EDTA, pH 7.8), and visualized by UV transillumination after staining with ethidium bromide $(0.5 \mu \mathrm{g} / \mathrm{ml})$. Where multiple amplicons were detected during the gel electrophoresis, single amplicons were excised from the gels and purified using the Promega Wizard ${ }^{\circledast}$ SV Gel and PCR Clean-Up (Wisconsin, USA), prior to sequencing.

\section{Gene cloning}

Clone libraries were created using the pGEM $^{\circledast}$-T Easy cloning kit from Promega (Wisconsin, USA) in accordance with the manufacturers instructions.

\section{DNA sequencing}

Automated DNA sequencing was performed using the PRISM Big Dye cycle sequencing system and a model 373 sequencer (Applied Biosystems, Foster City, CA).

\section{Bioinformatic analysis}

Sequence data were analysed using ABI Prism-Autoassembler software, while identity/similarity values to other translated sequences were determined using BLAST against the non-redundant (nr) data set, in conjunction with the National Center for Biotechnology Information (NIH, Bethesda, MD). Fugue blast http://wwwcryst.bioc.cam.ac.uk/fugue/ was used to identify distant homologs via sequence-structure comparisons. The gene clusters were assembled using the software package Phred,
Phrap, and Consed http://www.phrap.org/phredphrap consed.html, and open reading frames were identified manually.

\section{Phylogenetic analysis}

$16 \mathrm{~S}$ rDNA sequences of the studied cyanobacteria were retrieved from GenBank (Table 3). Sequence alignments were preformed using ClustalX [41] and were manually edited to exclude ambiguous regions. Maximum-likelihood phylogenetic trees were reconstructed using PhyML, with four gamma substitution rate categories and a 1000 bootstrap replicas [42] (available on-line at http:// atgc.lirmm.fr/phyml/). The optimal DNA substitution model for the data set $(\mathrm{GTR}+\mathrm{G})$ was identified using the $\mathrm{AiC}$ in the program Modeltest [43].

\section{Nucleotide sequence accession number}

Nucleotide sequences were submitted to GenBank. A. circinalis AWQC131C PST biosynthesis gene cluster is available under accession number DQ787201. Aph. sp. NH-5 PST biosynthesis gene cluster is available under accession number EU603710. A. circinalis 310F insertion excision sequence is available under accession number EU603709.

\section{Abbreviations}

PKS: polyketide synthase; PST: paralytic shellfish toxin; PSP: paralytic shellfish poisoning; STX: saxitoxin; GTX: gonyautoxin; dcSTX: decarbamoyl saxitoxin; neoSTX: neosaxitoxin; ACP: acyl carrier protein; PAPS: 5'-phosphoadenosine 3'-phosphosulfate.

\section{Authors' contributions}

TKM carried out all experimental work, acquired, analysed and interpreted data and drafted the manuscript. RK participated in drafting of the manuscript and data interpretation. BAN participated in drafting of the manuscript, experimental design, data interpretation and supervised the overall progress of this project.

\section{References}

I. Llewellyn LE: Saxitoxin, a toxic marine natural product that targets a multitude of receptors. Natural Product Reports 2006, 23:200-222.

2. Kaas H, Henriksen P: Saxitoxins (PSP toxins) in Danish lakes. Water Research 2000, 34(7):2089-2097.

3. Pereira $\mathrm{P}$, Onodera $\mathrm{H}$, Andrinolo $\mathrm{D}$, Franca $\mathrm{S}$, Araujo $\mathrm{F}$, Lagos $\mathrm{N}$, Oshima $Y$ : Paralytic shellfish toxins in the freshwater cyanobacterium Aphanizomenon flos-aquae, isolated from Montargil reservoir, Portugal. Toxicon 2000, 38(I 2): I689-I702.

4. Kao CY, Levinson SR, eds: Tetrodotoxin, saxitoxin, and the molecular biology of the sodium channel. New York: The New York Academy of Science; 1986.

5. Chang Z, Sitachitta N, Rossi JV, Roberts MA, Flatt PM, Jia J, Sherman $\mathrm{DH}$, Gerwick WH: Biosynthetic pathway and gene cluster analysis of curacin $A$, an antitubulin natural product from the tropical marine cyanobacterium Lyngbya majuscula. Journal of Natural Products 2004, 67(8): I 356-I 367.

6. Wang J, Salata JJ, Bennett PB: Saxitoxin is a gating modifier of HERG K+ channels. The Journal of General Physiology 2003, I 2 | (6):583-598. 
7. Hallegraeff GM: Harmful algal blooms: a global overview. Edited by: Hallegraeff GM, Anderson DM, Cembella AD. Manual on Harmful Marine Microalgae, UNESCO, Paris; 2003:25-49. ISBN 92340387I

8. Arakawa $O$, Noguchi $T$, Shida $Y$, Onoue $Y$ : Occurrence of carbamoyl-N-hydroxy derivatives of saxitoxin and neosaxitoxin in a xanthid crab Zosimus aeneus. Toxicon 1994, 32(2): I75-I83.

9. Arakawa $O$, Nishio $S$, Noguchi $T$, Shida $Y$, Onoue $Y$ : A new saxitoxin analogue from a xanthid crab Atergatis floridus. Toxicon 1995, 33( I 2): I577-1584.

10. Oshima Y: Postcolumn derivatization liquid chromatographic method for paralytic shellfish toxins. Journal of AOAC International 1995, 78(2):528-532.

II. Onodera H, Satake M, Oshima Y, Yasumoto T, Carmichael WW: New saxitoxin analogues from the freshwater filamentous cyanobacterium Lyngbya wollei. Natural Toxins 1997. 5(4): $|46-| 5 \mid$.

12. Zaman L, Arakawa O, Shimosu A, Shida Y, Onoue Y: Occurrence of a methyl derivative of saxitoxin in Bangladeshi freshwater puffers. Toxicon 1998, 36(4):627-630.

13. Negri A, Stirling D, Quilliam M, Blackburn S, Bolch C, Burton I, Eaglesham G, Thomas K, Walter J, Willis R: Three novel hydroxybenzoate saxitoxin analogues isolated from the dinoflagellate Gymnodinium catenatum. Chemical Research in Toxicology 2003 1 6(8): 1029-1033.

14. Shimizu Y: Chemistry and distribution of deleterious dinoflagellate toxins. Edited by: Faulkner D, Fenical W. New York: Plenum; 1977:26I-269.

15. Harada T, Oshima Y, Yasumoto T: Structure of two paralytic shellfish toxins, gonyautoxins $V$ and $V I$, isolated from a tropical dinoflagellate Pyrodinium bahamense var. compressa. Agricultural \& Biological Chemistry 1982, 46:| 86I- |864.

16. Oshima $Y$, Hasegawa M, Yasumoto T, Hallegaeff G, Blackburn S Dinoflagellate Gimnodium catenatum as the source of paralytic shellfish toxins in Tasmanian shellfish. Toxicon 1987, 25: II05-IIII.

17. Mahmood NA, Carmichael WW: Paralytic shellfish poisons produced by the freshwater cyanobacterium Aphanizomenon flos-aquae NH-5. Toxicon 1986, 24(2): I75-186.

18. Humpage AR, Rositano J, Bretag AH, Brown R, Baker PD, Nicholson $B C$, Steffensen DA: Paralytic shellfish poisons from Australian cyanobacterial blooms. Australian Journal of Marine \& Freshwater Research 1994, 45:761-77|.

19. Carmichael WW, Evans WR, Yin QQ, Bell P, Moczydlowski E: Evidence for paralytic shellfish poisons in the freshwater cyanobacterium Lyngbya wollei (Farlow ex Gomont) comb. nov. Applied \& Environmental Microbiology 1997, 63(8):3104-3।I0.

20. Lagos N, Onodera H, Zagatto PA, Andrinolo D, Azevedo S, Oshima $Y:$ The first evidence of paralytic shellfish toxins in the freshwater cyanobacterium Cylindrospermopsis raciborskii, isolated from Brazil. Toxicon 1999, 37( 1 0):1359-1373.

2I. Sawyer PJ, Gentile JH, Sasner JJJ: Demonstration of a toxin from Aphanisomenon flos-aquae (L.) Ralfs. Canadian Journal of Microbiology I968, I4(I I): I I99-I 204.

22. Li R, Carmichael WW, Liu Y, Watanabe MM: Taxonomic re-evaluation of Aphanizomenone flos-aquae NH-5 based on morphology and I6S rRNA gene sequences. Hydrobiologia 2000, 438:99-105.

23. Li R, Carmichael WW: Morphological and I6S rRNA gene evidence for reclassification of the paralytic shellfish toxin producing Aphanizomenon flos-aquae LMECYA 3I as Aphanizomenon issatschenkoi (Cyanophyceae). Journal of Phycology 2003, 39:8I4-8I8.

24. Beltran EC, Neilan BA: Geographical Segregation of the Neurotoxin-Producing Cyanobacterium Anabaena circinalis. Applied \& Environmental Microbiology 2000, 66( 10 ):4468-4474.

25. Bowling L, Baker P: Major cyanobacterial bloom in the BarwonDarling River, Australia, in and underlying limnological conditions. Marine \& Freshwater Research I991, 47(4):643-657.

26. Bowling L: The cyanobacterial (blue-green algae) bloom in the Darling/Barwon river system, November-December 1991. NSW Department of Water Resources, Technical Services Division, Report No. 92.074 1992:49. ISBN 0730578925

27. Baker PD, Humpage AR: Toxicity associated with commonly occurring cyanobacteria in surface waters of the Murray-
Darling Basin. Australian Journal of Marine \& Freshwater Research 1994, 45:773-786.

28. Llewellyn LE, Negri AP, Doyle J, Baker PD, Beltran EC, Neilan BA: Radioreceptor assays for sensitive detection and quantitation of saxitoxin and its analogues from strains of the freshwater cyanobacterium, Anabaena circinalis. Environmental Science \& Technology 200I, 35(7): |445- |45|.

29. Kellmann R, Mihali TK, Jeon YJ, Pickford R, Pomati F, Neilan BA: Biosynthetic Intermediate Analysis and Functional Homology Reveal a Putative Saxitoxin Gene Cluster in Cyanobacteria. Applied \& Environmental Microbiology 2008, 74(I3):4044-4053.

30. Kellmann R, Mihali TK, Neilan BA: Identification of a saxitoxin biosynthesis gene with a history of frequent horizontal gene transfers. Journal of Molecular Evolution 2008, 67:526-538.

31. Moffitt MC, Neilan BA: Characterization of the nodularin synthetase gene cluster and proposed theory of the evolution of cyanobacterial hepatotoxins. Applied \& Environmental Microbiology 2004, 70(I I ):6353-6362.

32. Yoshida T, Sako Y, Uchida A, Kakutani T, Arakawa O, Noguchi T, Ishida $Y$ : Purification and characterization of sulfotransferase specific to 0-22 of I I-hydroxy saxitoxin from the toxic dinoflagellate Gymnodinium catenatum (dinophyceae). Fisheries Science 2002, 68(3):634-642.

33. Sako Y, Yoshida T, Uchida A, Arakawa O, Noguchi T, Ishida Y: Purification and characterization of a sulfotransferase specific to $\mathrm{N}-2 \mathrm{I}$ of saxitoxin and gonyautoxin $2+3$ from the toxic dinoflagellate Gymnodinium catenatum (Dinophyceae). Journal of Phycology 200 I, 37(6): |044-I05I.

34. Mahillon J, Chandler $\mathrm{M}$ : Insertion sequences. Microbioogy and Molecular Biology Reviews 1998, 62(3):725-774. 1092-2172/98/

35. Rantala A, Fewer DP, Hisbergues M, Rouhiainen L, Vaitomaa J, Börner $T$, Sivonen K: Phylogenetic evidence for the early evolution of microcystin synthesis. Proceedings of the National Academy of Sciences 2004, 101 (2):568-573.

36. Mihali TK, Kellmann R, Muenchhoff J, Barrow KD, Neilan BA: Characterization of the gene cluster responsible for cylindrospermopsin biosynthesis. Applied \& Environmental Microbiology 2008, 74(3):716-722

37. Tillett $D$, Dittmann E, Erhard M, von Döhren $H$, Börner T, Neilan BA Structural organization of microcystin biosynthesis in Microcystis aeruginosa PCC7806: an integrated peptide-polyketide synthetase system. Chemistry \& Biology 2000, 7( I 0):753-764.

38. Thompson AS, Rhodes JC, Pettman I, eds: Culture collection of algae and protozoa. catalogue of strains. 5th edition. Natural Environment Research Council, Freshwater Biological Association; 1988:164.

39. Chenna R, Sugawara H, Koike T, Lopez R, Gibson TJ, Higgins DG, Thompson JD: Multiple sequence alignment with the Clustal series of programs. Nucleic Acids Research 2003, 3 I ( I3):3497-3500.

40. Siebert PD, Chenchik A, Kellogg DE, Lukyanov SA: An improved PCR method for walking in uncloned genomic DNA. Nucleic Acids Research 1995, 23:1087-1088.

4I. Thompson JD, Gibson TJ, Plewniak F, Jeanmougin F, Higgins DG: The CLUSTAL_ $X$ windows interface: flexible strategies for multiple sequence alignment aided by quality analysis tools. Nucleic Acids Research 1997, 25(24):4876-4882.

42. Guindon S, Gascuel O: A simple, fast, and accurate algorithm to estimate large phylogenies by maximum likelihood. Systematic Biology 2003, 52(5):696-704.

43. Posada $D$, Crandall KA: MODELTEST: testing the model of DNA substitution. Bioinformatics 1998, 14(9):817-818. 